\title{
Investigation on Parasitoids of Bark Beetles with New Host Record (Taphrorychus lenkoranus Reitter, 1913 (Curculionidae: Scolytinae)) from Northern Forests of Iran
}

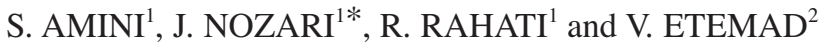 \\ ${ }^{1}$ Department of Plant Protection, College of Agriculture and Natural Resources, \\ University of Tehran, Karaj, Iran \\ ${ }^{2}$ Department of Forest, College of Agriculture and Natural Resources, University of Tehran, Karaj, Iran
}

(Received: 25 April 2016; accepted: 1 July 2016)

\begin{abstract}
The present study was carried out to identify parasitoids of bark beetles in the forests of northern Iran, from 2013-2015 (May-August). Four hymenopterans species belonging to 3 families (Eulophidae, Pteromalidae and Braconidae) were identified as Ecphylus silesiacus (Ratzeburg, 1848), Cheiropachus quadrum (Fabricius, 1787), Rhaphitelus maculatus Walker, 1834 and Entedon ergias (Ratzeburg, 1844). Among the identified bark beetles species, T. lenkoranus Reitter, 1913 was recorded as a new host of E. silesiacus for the first time in the world.
\end{abstract}

Keywords: Bark beetles, forest, Iran, new record, Hymenopterans.

Bark beetles of the subfamily Scolytinae (Coleoptera: Curculionidae) including more than 6,000 described species are found worldwide (Jordal, 2007). Scolytid are small size species that breed in phloem and destroy plant tissues, and some are important pests of forests and fruit orchard that cause considerable damage (Furniss and Carolin, 1977; Kuschel, 1995). Due to the economic and ecological importance of this subfamily, their biological control would be very important. Successful integrated pest management of bark beetles depends on accurate identification of natural enemies, some researchers have suggested that parasitoids have considerable effect on bark beetles population (Schvester, 1957; Moeck and Safranyik, 1984; Lotfalizadeh, 2012).

According to the recent studies, Hymenopterans parasitoids are the most important natural enemies of bark beetles (Mendel and Dagan, 1986; González and Campos, 1990; Zeiri et al., 2011). Parasitoids of bark beetles in the Palearctic region have been widely studied (Nuorteva, 1957; Peck, 1963; Trjapitzin, 1971; Herting, 1973; Zerova, 1978; Yang, 1996; Lotfalizadeh and Khalghani, 2008). Some important studies have been carried out in the world on parasitoids of bark beetles; for instance, Hedqvist (1998) published a book about chalcid and braconid parasitoids of bark beetles in Sweden. Nuorteva (1957) studied parasitoids of bark beetles in Finland. Maksimović (1979) carried out an

* Corresponding author; e-mail: nozari@ut.ac.ir

0238-1249/\$20.00 (C) 2016 Akadémiai Kiadó, Budapest 
investigation on parasitoids and reported several species such as Dendrostoter protuberans (Nees), Coleoides scolyticida wesm and Ecyphalus silesiacus (Ratz) as important parasitoids of bark beetles in Siberia. Miller (1983) provided a review of conifer bark beetle parasitoids in Europe, but parasitoids of broadleaf-feeding bark beetles were not widely reviewed. Several surveys have been carried out on Scolytus species as important vectors of Dutch elm disease (Maksimović, 1979; Mendel, 1986; Schroeder and Lindelow, 1989; Manojlovic et al., 2000). In other study on almond bark beetles species, three new species, Cheiropachus quadrum, Rhaphitelus maculatus and Eusandalum merceti, were reported in Tunisia (Zeiri et al., 2013). Parasitoids of Phloeotribus scarabaeoides (Bernard) a destructive pest on olive plantations was studied by several authors (Russo, 1938; González and Campos, 1990).

Although Scolytid species are among the most important pest in forests of northern Iran, only few studies have been published on their natural enemies in this area. Basiri et al. (2013) have reported Dendrosoter middendorffii (Ratzeburg, 1848) as a parasitoid of Scolytus rugulosus from Northern and Western fruit orchards of Iran. Moreover, Lotfalizadeh (2010) recorded Coelopencyrtus callidii (Jansson, 1957) as parasitoid of bark beetles in Northwest of Iran.

Based on the importance of scolytid damage in forest of Iran (Lotfalizadeh, 2010), identification of parasitoids is an important step in the biological control of pests. Therefore, the aim of this study is to identify the parasitoids of bark beetles and their hosts in the forests of Northern Iran.

\section{Materials and Methods}

Sampling was randomly carried out by direct observation. The branches of infested trees were collected from different localities of forest in Guilan, Mazandaran and Golestan provinces in Iran. The exact position of sampling areas are shown in Table 1. Samples were collected from Carpinus sp., Prunus sp., Malus sp. and Fagus orienta-

\section{Table 1}

Collection site data north forest of Iran

\begin{tabular}{|c|c|c|c|}
\hline Location & & Position & Host plant \\
\hline Guilan & N $37^{\circ} 09^{\prime} 36^{\prime \prime}$ & E $50^{\circ} 34^{\prime} 28^{\prime \prime}$ & Prunus sp. \\
\hline Guilan & $\mathrm{N} 37^{\circ} 09^{\prime} 46^{\prime \prime}$ & E $49^{\circ} 24^{\prime} 07^{\prime \prime}$ & Malus sp. \\
\hline Guilan & $\mathrm{N} 37^{\circ} 16^{\prime} 32^{\prime \prime}$ & E $49^{\circ} 33^{\prime} 49^{\prime \prime}$ & Prunus sp. \\
\hline Golestan & N $36^{\circ} 53^{\prime} 21^{\prime \prime}$ & E $54^{\circ} 53^{\prime} 24^{\prime \prime}$ & Fagus sp. \\
\hline Golestan & N $36^{\circ} 49^{\prime} 95^{\prime \prime}$ & $\mathrm{E} 54^{\circ} 41^{\prime} 00^{\prime \prime}$ & Fagus sp. \\
\hline Mazandaran & $\mathrm{N} 36^{\circ} 29^{\prime} 42^{\prime \prime}$ & E $51^{\circ} 39^{\prime} 49^{\prime \prime}$ & Prunus sp. \\
\hline Mazandaran & N $36^{\circ} 33^{\prime} 36^{\prime \prime}$ & E $51^{\circ} 36^{\prime} 29^{\prime \prime}$ & Carpinus sp. \\
\hline Mazandaran & N $36^{\circ} 29^{\prime} 26^{\prime \prime}$ & E $51^{\circ} 39^{\prime} 29^{\prime \prime}$ & Carpinus sp. \\
\hline
\end{tabular}


lis in 2013-2015 from May-August. Collected branches contained larval stages of bark beetles in their galleries. For rearing the beetles, the collected branches were cut off into $50 \mathrm{~cm}$ long pieces and put in the rearing boxes $(2 * 2 * 1)$ separately under suitable conditions in insectarium. Moisture was $70 \%$ temperature at $25{ }^{\circ} \mathrm{C}$ and the photoperiod was $16 \mathrm{~h} \mathrm{light} / 8 \mathrm{~h}$ dark. After 10-15 days, adults of hymenoptera emerged and were collected daily, counted and put into vials containing $90 \%$ ethanol and then mounted for morphological identifications. Bark beetles were collected under the bark of trees and counted. All specimens were identified by authors based on relevant keys such as Hedqvist (1998), Farahani and Talebi (2012) and Pfeffer (1995). Species were confirmed by specialists such as Dr. Michail Mandelshtam (Centre for Bioinformatics and Genome Research, Saint-Petersburg State Forest Technical University - Russia), Dr. Gary Gibson (Associate professor, Canadian National Collection of Insects (CNC), Dr. Hossein Lotfalizadeh (Head of East-Azarbaijan Research Center for Agriculture and Natural Resources Tabriz) and Dr. Samira Frahani (Research Institute of Forests and Rangelands, Agricultural Research Education and Extension Organization (AREEO), Tehran, Iran). Photographs were taken by Dino-lite AM-423 X attached to binocular Olympus SZ11. Identified samples were labeled with necessary information and deposited in Zoology Museum, University of Tehran, Iran.

\section{Results and Discussion}

In this study, a total of 151 specimens of parasitoids, belonging to four species were reared and identified. These are E. silesiacus (Ratzeburg, 1848) (Hym:Braconidae), C. quadrum (Fabricius, 1787) (Hym:Peteromalidae), R. maculatus Walker, 1834 (Hym:Peteromalidae) and E. ergias (Ratzeburg, 1844) (Hym:Eulophidae). During the rearing of E. silesiacus, no adult beetles emerged and during dissecting of the logs, parasitized beetles were observed in larval and pupal stages. In total, two adult beetles were identified as S. rugulosus (Muller, 1818) and T. lenkoranus Reitter, 1913 (Table 2). E. silesiacus was counted as 85 specimens and is the most abundant species among other parasitoids (Table 2) that was first recorded by Aubert (1966) from Iran. Maksimović (1979) stated that it is one of the most important parasitoids of bark beetles found on Ulmus such as Scolytus multistriatus and S. scolytus species. This species can be distinguished from

Table 2

Number of reared hymenoptera species

\begin{tabular}{lccl}
\hline Species & $\begin{array}{c}\text { Number of parasitoids } \\
\text { emerged }\end{array}$ & $\begin{array}{c}\text { Number of branches } \\
\text { in } 50 \mathrm{~cm} \text { long }\end{array}$ & Host bark beetle \\
\hline Cheiropachus quadrum & 26 & 3 & Scolytus rugulosus \\
Ecphylus silesiacus & 85 & 2 & Taphrorychus lenkoranus \\
Entedon ergias & 12 & 1 & Scolytus rugulosus \\
Rhaphitelus maculatus & 28 & 2 & Scolytus rugulosus \\
\hline
\end{tabular}




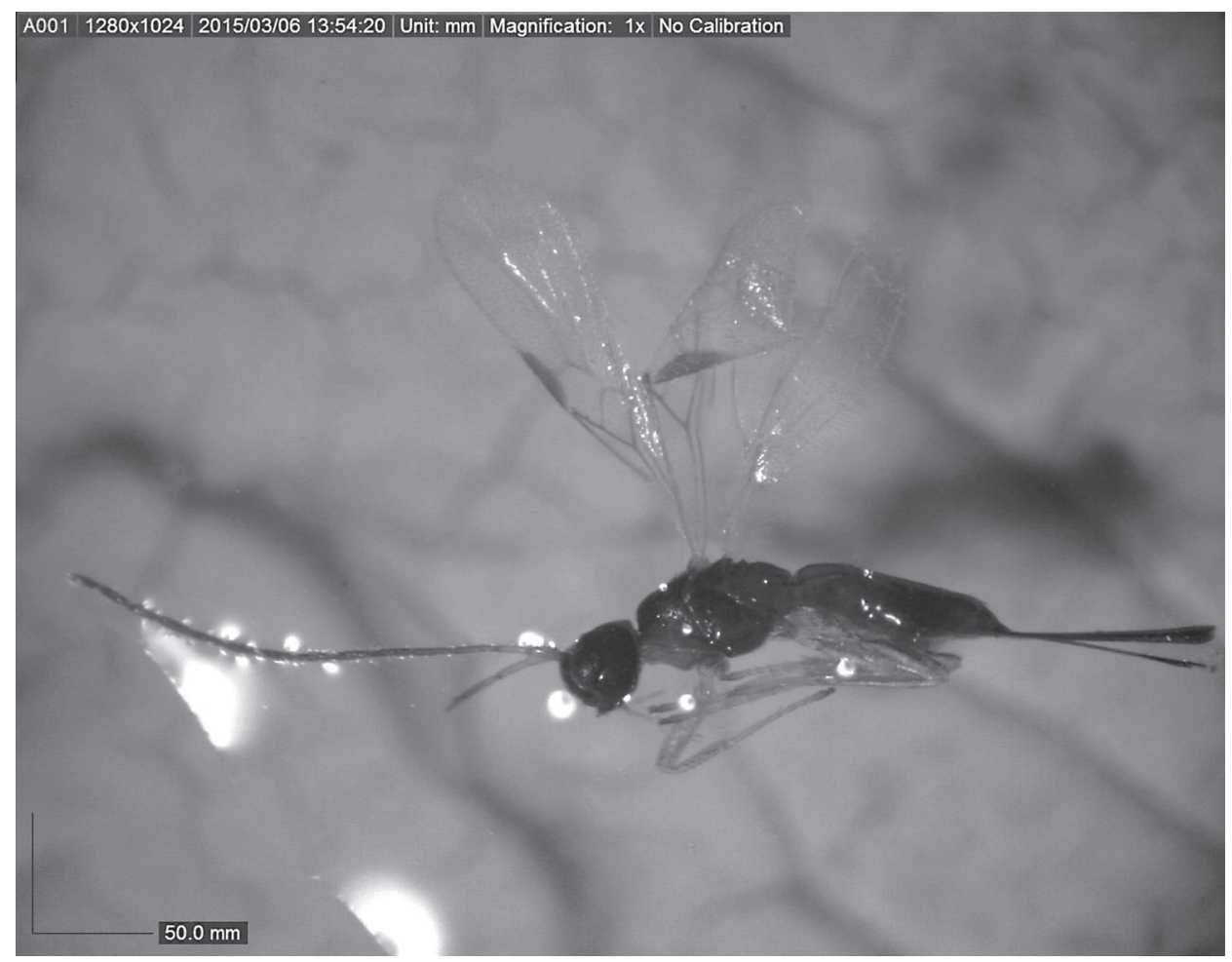

Fig. 1. Ecphylus silesiacus (Female)

closely related species like E. caudatus by the following morphological characters: body color is dark brown to black; absence of $\mathrm{Cu}$ vein in forewing, developed costal vein in hind wing and closed basal cell; ovipositor as long as the abdomen (Farahani et al., 2014) (Fig. 1). In recent studies, several hosts were recorded for E. silesiacus such as Dryocoetes villosus (Fabricius, 1792), Orthomicus laricis (Fabricius, 1792), Ipstypo graphus (Linnaeous, 1758), Ptelobious vitatus (Fabricius, 1787), and Trypodendron domesticum (Linnaeous, 1758), but in this study, a new host called T. lenkoranus was identified for the first time. T. lenkoranus is an important pest in the forests of northern Iran. This species was collected for the first time by Amini et al. (2013) from Guilan province. The most important morphological characters of T. lenkoranus are as follows: Body length is $1.8-2.3 \mathrm{~mm}$, cylindrical, dark brown, covered by long hairs. The frons in male were covered with short and sporadic hairs; female with topknot hair in the middle with projections Pronotum cylindrical, longer in width Pronotom with projections anteriorly and dotted posteriorly; elytra covered with large striated punctures. The back slope of elytra in female was concave and in male, it was more or less flattened with a shining circular surface and small punctures; length of elytra was 1.65-1.75 mm (Pfeffer, 1995) (Fig. 2).

The second identified parasitoid, C. quadrum is a common parasitoid of bark beetles and other xylophages (Lotfalizadeh, 2012). It has remarkable morphological char- 
acters including: two transverse marking on forewings; thickened fore and hind femur, hind tibia and a row of spines in dorsal and easily recognize by the combination of a large propleura, enlarged fore femora and maculate forewings (Mitroiu et al., 2011) (Fig. 3).

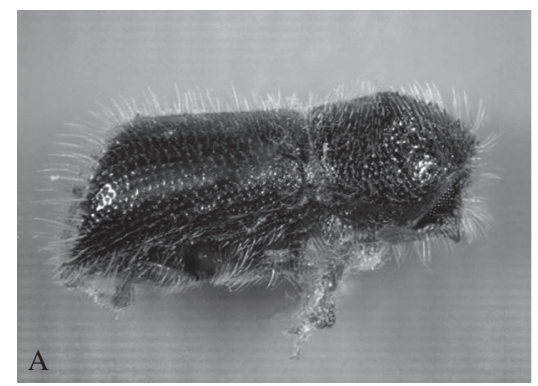

Fig. 2A. Taphrorychus lenkoranus. Lateral view (male)

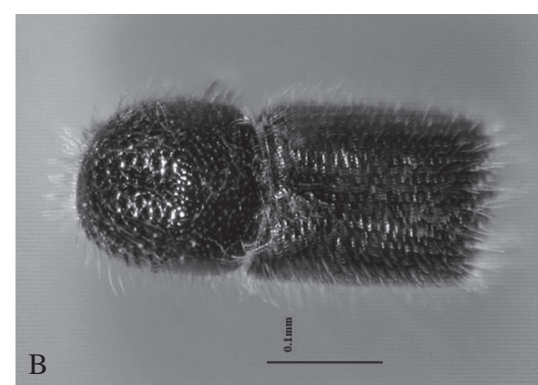

Fig. 2B. Taphrorychus lenkoranus. Dorsal view (male)

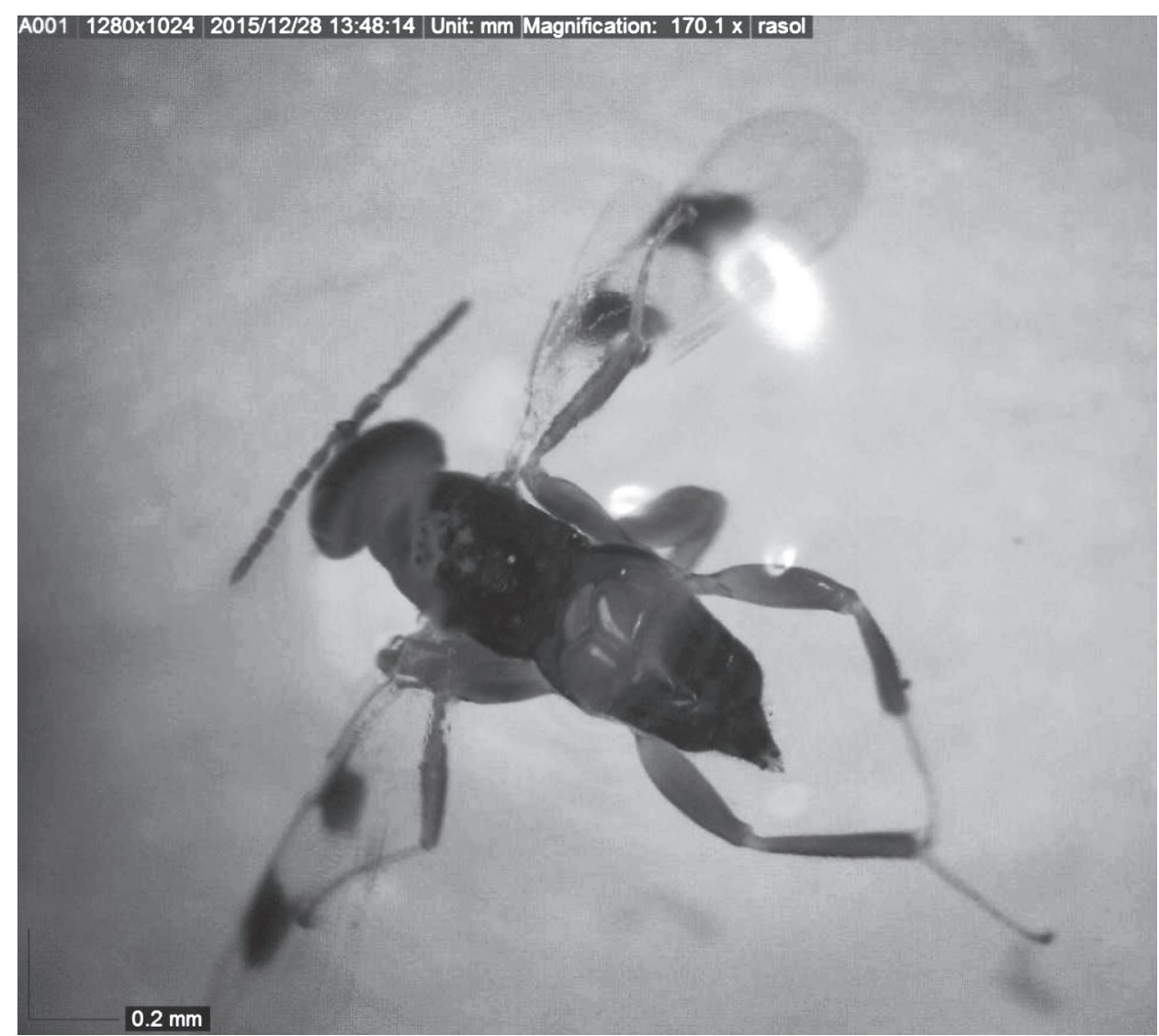

Fig. 3. Cheiropachus quadrum (male) 
Lotfalizadeh and Gharali (2008) reported this species on S. rugulosus on fruit orchards. This species was recorded from East Azerbaijan, Iran (Lotfalizadeh, 2002).

R. maculatus was first reported from Iran by Radjabi (1989) from Markazi, Zanjan, Hamedan and Esfahan Provinces then Lotfalizadeh (2012) collected it from East Azerbaijan and Davatchi and Chodjai (1968) reported it from Karaj and Ardebil. This species has short club-like antenna and a few erect setae on hind coxa (Fig. 4).

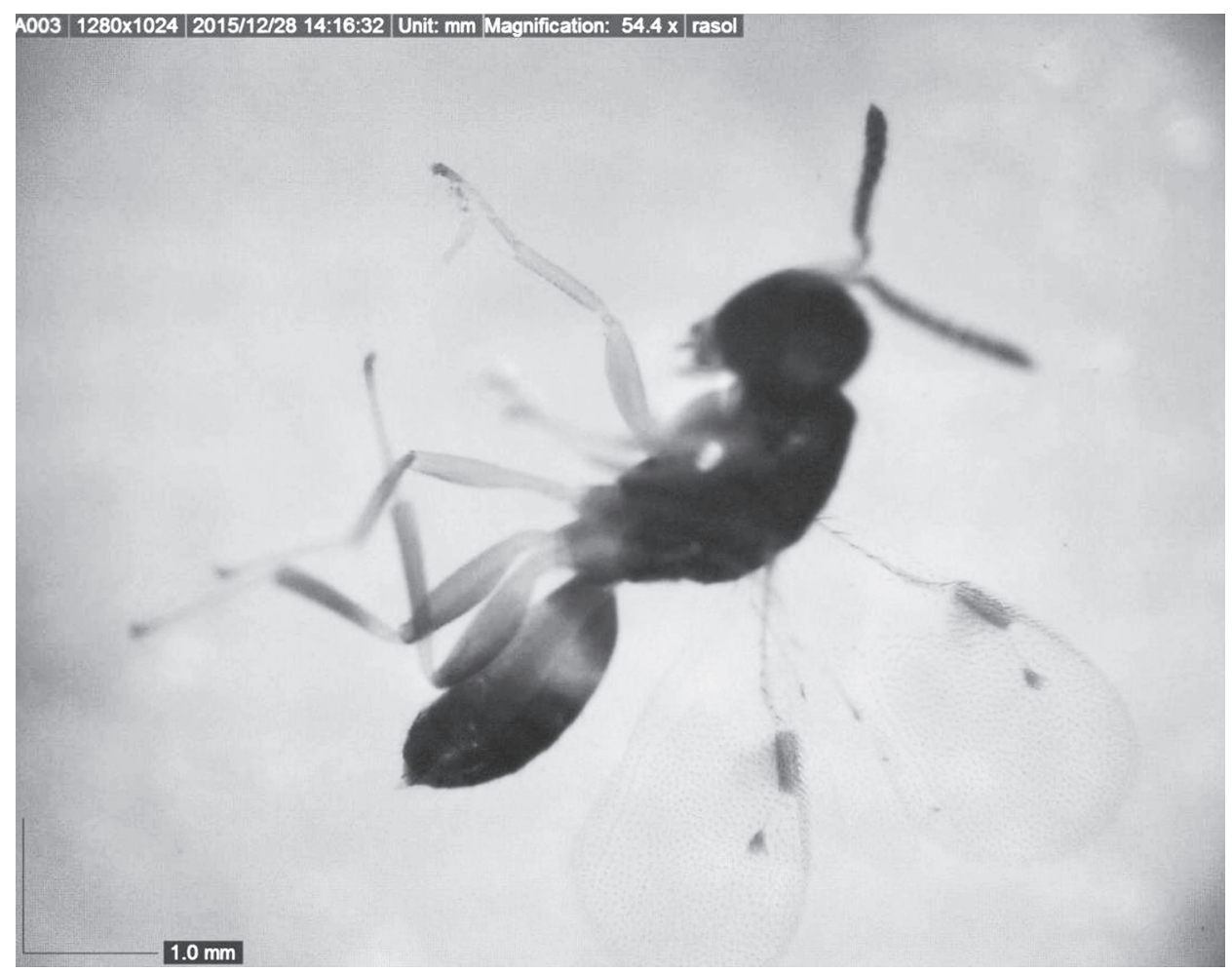

Fig. 4. Rhaphitelus maculatus (male)

E. ergias has been reared from S. rugulosus from Markazi, Tehran Zanjan province (Davatchi and Chodjai, 1968; Radjabi, 1989). This species is distributed worldwide including Austria, Canada, Germany, Italy, Russia, America, France and Czech Republic. Body size is $1.5-2 \mathrm{~mm}$. Color is black. Head is wide, antennae is short and geniculate, vein is consumptive and the wing is covered by setae (Basiri et al., 2013).

The numbers of parasitoids and their host is given in Table 1. The authors mentioned about the numbers of branches that parasitoids emerged, too (Table 1). 
Table 3

List of parasitoid wasps in the family Braconidae that have been reported to attack bark beetles in Palearctic region (Wegensteiner et al., 2015)

\begin{tabular}{|c|c|}
\hline Species & Host bark beetle genus \\
\hline Blacus humilis (Nees, 1811) & Tomicus \\
\hline Blacus koenigi Fischer 1965 & Tomicus \\
\hline Bracon hylobii Ratzeburg, 1848 & Polygraphus \\
\hline Bracon obscurator Nees, 1811 & Pityogenes \\
\hline Bracon palpebrato Ratzeburg 1844 & Tomicus \\
\hline Bracon stablis Wesmael 1838 & Hylesinus \\
\hline Bracon tenuicornis Wesmael 1838 & Phloeotribus \\
\hline Caenopachys caenopachoides (Ruschka, 1925) & Orthomicu, Pityogenes \\
\hline Caenopachys hartigii (Ratzeburg, 1848) & Pityogenes \\
\hline Cenocoelius nigrisoma (Rohwer, 1914) & Dendroctonus, Ips \\
\hline Centistes cuspidatus Haliday, 1835 & Lepersinus \\
\hline Coeloides abdominalis (Zetterstedt, 1838) & Ips, Pityogenes \\
\hline Coeloides bostrichorum Giraud 1872 & Cryphalus, Ips, Pityogenes, Pityokteines \\
\hline Coeloides filiformis Ratzeburg, 1852 & Hylesinus, Lepersinus, Phloeotribus \\
\hline Coeloides melanotus Wesmael, 1838 & Hylesinus, Lepersinus, Phloeotribus \\
\hline Coeloides scolyticida (Ashmead, 1889) & Lepersinus, Scolytus \\
\hline Coeloides sordidator Ratzeburg 1844 & Ips, Scolytus, Tomicus \\
\hline Coeloides subconcolor Russo, 1938 & Lepersinus, Phloeotribus \\
\hline Coeloides ungularis Thomson, 1892 & Scolytus \\
\hline Cosmophorus cembrae Ruschka, 1925 & Cryphalus, Pityogenes \\
\hline Cosmophorus klugii Ratzeburg, 1848 & Pityogenes, Ips, Pityokteines \\
\hline Cosmophorus regius Niezabitowski, 1910 & Hylurgops, Ips, Orthomicus, Polygraphus, Pityokteines \\
\hline Cryptoxilos cracoviensis Muesebeck, 1936 & Cryphalus \\
\hline Caenopachys hartigii (Ratzeburg, 1848) & Ips, Orthomicus, Polygraphus, Pityogenes \\
\hline Dendrosoter middendorffii (Ratzeburg, 1848) & $\begin{array}{l}\text { Ips, Orthomicus, Cryphalus, Dendroctonus, Polygraphus, } \\
\text { Pityogenes, Pityokteines }\end{array}$ \\
\hline Dendrosotinus ferrugineus (Nees, 1834) & Phloeotribus \\
\hline Dendrosotinus similes & Cryphalus \\
\hline Doryctes pomarius Reinhard, 1865 & Scolytus \\
\hline Ecphylus caudatus Ruschka, 1916 & Cryphalus \\
\hline Ecphylus eccoptogastri (Ratzeburg, 1848) & Phloeotribus, Scolytus \\
\hline Ecphylus hylesini (Ratzeburg, 1848). & Polygraphus, Pityogenes, Pityokteines, Ips, Tomicus \\
\hline Ecphylus silesiacus (Ratzeburg, 1848) & Cryphalus, Scolytus, Phloeotribus, Pityogenes, Pityokteines \\
\hline
\end{tabular}


Table 3 (cont.)

\begin{tabular}{ll}
\hline Species & \\
\hline Hecabolus sulcatus Curtis, 1834 & Phloeosinus bark beetle genus \\
Heterospilus ater Fischer 1960 & Scolytus \\
Heterospilus incompletus (Ratzeburg 1844) & Phloeosinus \\
Heterospilus sicanus (Marshall, 1888) & Cryphalus \\
Lysitermus pallidus Foerster, 1862 & Polygraphus \\
Meteorus consimilis (Nees 1834). & Scolytus \\
Meteorus obfuscatu (Nees, 1811). & Scolytus \\
Monolexis fuscicornis Forster, 1862 & Phloeotribus \\
Ontsira antica (Wollaston, 1858). & Hylurgops, Orthotomicus, Ips \\
Perilitus rutilus (Nees, 1812) & Pityokteines \\
Rhoptrocentrus piceus Marshall 1897 & Phloeotribus \\
Ropalophorus clavicornis (Wesmael, 1835) & Ips \\
Spathius brevicaudis (Ratzeburg, 1844) & Scolytus \\
Spathius curvicaudis Ratzeburg, 1844 & Scolytus \\
Spathius rubidus (Rossi, 1794) & Scolytus, Phloeotribus \\
\hline
\end{tabular}

\section{Table 4}

List of parasitoid wasps in the family Pteromalidae that have been reported to attack bark beetles in Palearctic region (Wegensteiner et al., 2015)

\begin{tabular}{ll}
\hline Parasitoids species & \multicolumn{1}{c}{ Bark beetle genus } \\
\hline Acrocormus semifaciatus Thomson, 1878 & Scolytus \\
Agrilocida ferrierei Steffan, 1964 & Scolytus \\
Cerocephala cornigera (Westwood, 1832) & Scolytus, Phloeotribus, Lepersinus \\
Cerocephala eccoptogastri Masi, 1921 & Scolytus, Phloeotribus, Lepersinus, Phloeosinus \\
Cheiropachus quadrum (F. 1848) & Scolytus, Phloeotribus, Lepersinus, Ips \\
Cleonymus brevis Boucek, 1972 & Scolytus \\
Cleonymus obscurus Walker, 1837 & Scolytus \\
Dinotiscus aponius (Walker, 1848) & Scolytus, Hylesinus, Lepersinus \\
Dinotiscus colon (Linnaeus, 1758) & Scolytus, Ips, Phloeotribus \\
Dinotiscus eupterus (Walker, 1836) & Dendroctonus, Cryphalus, Pityophtoru, Ips, Pityokteines, \\
Habritys brevicornis (Ratzeburg, 1844) & Pityophtorus, Pityogenes, Polygraphus \\
Heydenia praetiosa Förster, 1856 & Leperisinus, Ips, Orthotomicus, Phloeosinus, Phloeotribus, \\
Macromesus amphiterus & Pityogenes, Tomicus, Scolytus, Pityokteines \\
Mesopolobus typographi (Ruschka, 1924) & Polygraphus, Ips, Pityogenes \\
\hline
\end{tabular}


Table 4 (cont.)

\begin{tabular}{ll}
\hline Parasitoids species & \multicolumn{1}{c}{ Bark beetle genus } \\
\hline Metacolus azureus (Ratzeburg, 1844) & Ips, Orthomicus, Pityogenes \\
Metacolus unifasciatus Förster, 1856 & Tomicus, Orthomicus, Phloeosinus \\
Perniphora robusta Ruschka, 1923 & Trypodendron, Ips \\
Platygerrhus affinis (Walker, 1836) & Ips \\
Platygerrhus dolosus (Walker, 1836) & Scolytus \\
Platygerrhus ductilis (Walker, 1836) & Scolytus \\
Platygerrhus maculatus Erdös, 1957 & Scolytus \\
Pteromalus abieticola Ratzeburg, 1848 & Pityogenes \\
Pteromalus brunnicans Ratzeburg 1848 & Scolytus \\
Rhaphitelus ladenbergii (Ratzeburg, 1844) & Scolytus \\
Rhaphitelus maculatus Walker, 1834 & Scolytus \\
Rhopalicus guttatus (Ratzeburg, 1844) & Tomicus \\
Rhopalicus quadratus (Ratzeburg, 1844) & Tomicus, Phloeosinus, Ips, Pityogenes \\
Rhopalicus tutela (Walker, 1836) & Dendroctonus, Ips, Pityogenes, Tomicus, Scolytus, Polygraphus \\
Roptrocerus brevicornis Thomson 1878 & Ips, Pityogenes, Tomicus \\
Roptrocerus mirus (Walker, 1834) & Ips, Tomicus, Polygraphus, Pityogenes \\
Roptrocerus xylophagorum Ratzeburg, 1844 & Dendroctonus, Cryphalus, Orthotomicus, Ips \\
Tomicobia acuminati Hedqvist, 1959 & Ips \\
Tomicobia pityophthori (Boucek, 1955) & Ips, Pityogenes, Pityophtorus \\
Tomicobia seitneri (Ruschka, 1924) & Ips \\
Trigonoderus princeps Westwood, 1832 & Ips \\
\hline
\end{tabular}

\section{Conclusion}

Bark beetles are among the most important forest pests of Iran (Amini et al., 2013) and Hymenopterous parasitoids are likely the most effective natural enemies in their biological control (Russo, 1938; Mendel and Dagan, 1986; González and Campos, 1990; Zeiri et al., 2011). In this study, four parasitoid species of bark beetles were identified as E. silesiacus (Ratzeburg, 1848), C. quadrum (Fabricius, 1787), R. maculatus Walker, 1834 and E. ergias (Ratzeburg, 1844). Two hosts were identified and T. lenkoranus was recorded for the first time as a new host for E. silesiacus. During the rearing of E. silesiacus, no bark beetles emerged. Results of this study showed that E. silesiacus parasites are all bark beetles in larval and pupal stage and were the most abundant parasitoid. Recent studies showed that $E$. silesiacus has an important role in reducing the population level of bark beetle (Stojanovic and Markovic, 2007). Finally according to recent studies and result of this present study there are nearly more than 100 species which parasite bark beetles. The list of parasitoids and their host in Palearctic region is mentioned in below 
tables (Basiri et al., 2013; Wegensteiner et al., 2015) (Table 3 and Table 4). Among these parasitoids of bark beetles, the most abundant species are belong to Pteromalidae family and nearly 50 species are in Braconidae family. The result in present study is in line with the results of other studies. Nevertheless, due to the high diversity of bark beetles and effective role of parasitoids in controlling them, there is need for further studies of parasitoids in forest.

\section{Acknowledgements}

Authors wish to special thanks to Dr. Michail Mandelshtam (Centre for Bioinformatics and Genome Research, Saint-Petersburg State Forest Technical University - Russia) and Dr. Hossein Lotfalizadeh (Head of East-Azarbaijan Research Center for Agriculture and Natural Resources Tabriz) for confirmed morphological identification. and Dr. Frazane Kazerani (PhD candidate University of Tabriz) for her thoughtful comments.

\section{Literature}

Amini, S., Hosseini, R. and Sohani, M. M. (2013): A faunal study of bark beetles (Coleoptera: Curculionidae: Scolytinae) in Guilan province in North of Iran. Entomofauna 34, 169-176.

Aubert, J. F. (1966): Liste d'identification No. 6 (présentée par le service d'identification des Entomophages). Entomophaga 11, 115-134.

Basiri, N. H., Lotfalizadeh, H. and Kazemi M. H. (2013): Dendrosoter middendorffii (Ratzeburg, 1848) (Hymenoptera: Braconidae) a parasitoid of the fruit bark beetles in Iran. Biharean Biologist 7, 104-105.

Davatchi, A. and Chodjai, M. (1968): Les Hyménoptères entomophages de l'IRAN - études faunéstiques. Iranian Plant Protection Congress, October, Tehran, Iran. [In Persian].

Farahani, S. and Talebi, A. A (2012): A review of the tribe Meteorini (Cresson, 1887) (Hymenoptera: Braconidae, Euphorinae) in Northern Iran, with eight new records. Iran. J. Anim. Biosyst. 8, 133-153.

Farahani, S., Talebi, A. A., Rakhshani, E. and van Achterberg, C. (2014): Wasps of the subfamily Doryctinae (Hymenoptera: Braconidae) in Iran. Zool. Middle East. 1, 65-81.

Furniss, R. L. and Carolin, V. M. (1977): Western forest insects. U.S.D.A. Forest Service Misc. Publ. 1339, $654 \mathrm{p}$.

González, R. and Campos, M. (1990): Rearing of Cheiropachus quadrum (Hym.: Pteromalidae) from the olive beetle, Phloeotribus scarabaeoides (Col.: Scolytidae). Potential biological control agent. Redia 73, 495505.

Hedqvist, K. J. (1998): Bark-beetle enemies in Sweden II. Braconidae (Hymenoptera). Entomol. Scand. 52, $1-87$.

Herting, B. (1973): A catalogue of parasites and predators of terrestrial arthropods Section A Host or Prey/ Enemy Vol. 3. Coleoptera to Strepsiptera. Commonwealth Agricultural Bureaux, 185 p.

Jordal, B. H. (2007): Reconstructing the phylogeny of Scolytidae and close allies: major obstacles and prospects for a solution. In: B. Bentz, A. Cognato, K. Raffa (eds): Proceedings from the Third Workshop on Genetics of Bark Beetles and Associated Microorganisms. Proc. RMRS-P-45.

Kuschel, G. (1995): A phylogenetic classification of Curculionoidea to families and subfamilies. Mem. Entomol. Soc. Wash. 14, 5-33.

Lotfalizadeh, H. (2002): Parasitoids of cabbage aphid, Brevicoryne brassicae (L.) (Hom.: Aphididae) in Moghan Region. Agr. Sci. 12, 15-25.

Lotfalizadeh, H. (2010): Some new data and corrections on Iranian encyrtid wasps (Hymenoptera: Chalcidoidea, Encyrtidae) fauna. Biharean Biologist 4, 173-178. 
Lotfalizadeh, H. (2012): Review of chalcidoid parasitoids (Hymenoptera: Chalcidoidea) of xylophagous beetles. Munis Entomol. Zool. 7, 309-333.

Lotfalizadeh, H. and Gharali, B. (2008): Pteromalidae (Hymenoptera: Chalcidoidea) of Iran: New records and a preliminary checklist. Entomofauna 29, 93-120.

Lotfalizadeh, H. and Khalghani, J. (2008): Hymenopterous parasitoids (Hym.: Chalcidoidea) of xylophagous beetles in Iran. Entomofauna 29, 249-264.

Maksimović, M. (1979): Influence of the density of bark beetles and their parasites on dieback of elm in some woods of Yugoslavia. Z. Angew Entomol. 88, 283-295.

Manojlovic, N. T., Solujic, S., Sukdolak, S. and Krstic, L. (2000): Isolation and antimicrobial activity of anthraquinones from some species of the lichen genus Xanthoria. J. Serbian Chemical Society 65, 555-560.

Mendel, Z. (1986): Hymenopterous parasitoids of bark beetles [Scolytidae] in Israel: Host relation, host plant, abundance and seasonal history. Entomophaga 31, 113-125.

Mendel, Z. and Dagan, B. (1986): Hymenopterous parasitoids of bark beetles [Scolytidae] in Israel: relationships between host and parasitoid size, and sex ratio. Entomophaga 31, 127-137.

Miller, M. C. (1983): Lightning strike simulation for studying southern pine bark and engraver beetle attacks. USDA Forest Service Research 4, 245-296.

Mitroiu, M. D., Abolhassanzadeh, F. and Madjdzadeh, S. M. (2011): New records of Pteromalidae (Hymenoptera: Chalcidoidea) from Iran, with description of a new species. North-Western J. Zool. 7, 243-249.

Moeck, H. A. and Safranyik, L. (1984): Assessment of predator and parasitoid control of bark beetles. Canadian Forestry Service, Pacific Forestry Centre NO.BC-X-248.

Nuorteva, M. (1957): Zur kenntnis der parasitischen hymenopteren der borkenkäfer Finnlands. Annales Entomologici Fennici 23, 118-121.

Peck, O. (1963): A catalogue of the nearctic Chalcidoidea (Insecta: Hymenoptera). Mem. Entomol. Soc. Can. 95, 5-1092.

Pfeffer, A. (1995): Central und Westpaläarktische Borkenund Kernkäfer (Coleoptera: Scolytidae, Platypodidae) [(Central and Western Palearctic bark beetles and pinhole borers (Coleoptera: Scolytidae, Platypodidae)]. Pro Entomologia, Naturhistorisches Museum, Basel 310 p.

Radjabi, G. R. (1989): Insects attacking rosaceous fruit trees in Iran. Homoptera. Plant Pests and Diseases Reserch Institute Tehran 3, 256 p.

Russo, G. (1938): Contribution to the knowledge of Phloeotribus scarabaeoides BERN. (Coleoptera, Scolytidae). Bollettino del Laboratorio di Zoologia Generale e Agraria della R. Istituto Superiore d'Agricoltura Portici 16-17, 3-419 (in Italian).

Schroeder, L. M. and Lindelow, A. (1989): Attraction of scolytids and associated beetles by different absolute amounts and proportions of $\alpha$-pinene and ethanol. J. Chem. Ecol 15, 807-818.

Schvester, D. (1957): Contribution à l'étude écologique des coléoptères scolytides: essai d'analyse des facteurs de fluctuation des populations chez Ruguloscolytus rugulosus Muller1818. Ann. Epiphyt 8, 1-162.

Stojanovic, A. and Markovic, Č. (2007): The hymenopteran parasitoids of some elm bark beetles in Serbia. Phytoparasitica 35, 239-243.

Trjapitzin, V. A. (1971): Encyrtidae (Hymenoptera, Chalcidoidea) collected by ES Sugonjaev in Afghanistan. Entomological Essays to Commemorate The Retirement of Professor Yasumatsu, Tokyo. pp. 119-127.

Wegensteiner, R., Wermelinger, B. and Herrmann, M. (2015): Natural enemies of bark beetles: predators, parasitoids, pathogens, and nematodes. In: F. E. Vega and R. W. Hofstetter (eds): Bark Beetles. Academic Press, pp. 247-304.

Yang, Z. Q. (1996): Parasitic Wasps on Bark Beetles in China (Hymenoptera). Science Press, Beijing, 351 p.

Zeiri, A., Braham, M. and Braham, M. (2011): First Record of Cephalonomia hypobori on Scolytus amygdali in Tunisia. Tunisian J. Plant Prot. 6, 43-47.

Zeiri, A., Braham, M. and Braham, M. (2013): Parasitoids of the almond bark beetle Scolytus amygdali in Tunisia. Tunisian J. Plant Prot. 8, 45-56.

Zerova, M. (1978): Hymenoptera Parasitica. Chalcidoidea-Eurytomidae Fauna Ukraini 11, 1-465. 